\section{Nutrient Management of Nursery Runoff Water using Constructed Wetland Systems}

\author{
Milton D. Taylor ${ }^{1}$, Sarah A. White 2 , Stewart L. Chandler ${ }^{3}$, \\ Stephen J. Klaine ${ }^{4}$, and Ted Whitwell ${ }^{5}$
}

ADDITIONAL INDEX WORDs. container nursery, nitrogen, phosphorus, surface-flow wetlands, compartmentalization, remediation

\begin{abstract}
SumMARY. Substantial quantities of water and nutrients are required for the production of high value nursery and greenhouse crops. As water quality criteria are strengthened locally and nationally, horticultural enterprises will have to meet stricter limits on nutrients in discharge water. This study examined the efficacy of an established vegetated surface-flow constructed wetland to mediate nitrogen $(\mathrm{N})$ and phosphorus $(\mathrm{P})$ in runoff water from a commercial nursery over a period of 38 months. Maximum oxidized nitrogen [nitrate- $\mathrm{N}\left(\mathrm{NO}_{3}-\mathrm{N}\right)$ + nitrite- $\mathrm{N}\left(\mathrm{NO}_{2}-\mathrm{N}\right)$ ] inputs occurred during the spring fertilization period of March through May (11.1 to $\left.29.9 \mathrm{mg} \cdot \mathrm{L}^{-1} \mathrm{~N}\right)$ and minimum inputs occurred during winter plant dormancy between December and February (2.8 to 5.2 $\left.\mathrm{mg} \cdot \mathrm{L}^{-1} \mathrm{~N}\right)$. Nitrogen remediation efficiency averaged $94.7 \%$ for March through November sampling dates but declined to a mean of $70.7 \%$ between December and February when mean wetland water temperature dropped below $15^{\circ} \mathrm{C}$. Orthophosphate phosphorus $\left(\mathrm{PO}_{4}-\mathrm{P}\right)$ concentrations in nursery runoff showed no dramatic changes over months, seasons, or years. Mean wetland influent orthophosphate concentration ranged from 0.7 to $2.2 \mathrm{mg} \cdot \mathrm{L}^{-1} \mathrm{PO}_{4}-\mathrm{P}$ with an overall mean of $1.41 \mathrm{mg} \cdot \mathrm{L}^{-1} \mathrm{PO}_{4}-\mathrm{P}$ for all months sampled. Mean discharge orthophosphate concentration ranged from 0.5 to $2.1 \mathrm{mg} \cdot \mathrm{L}^{-1} \mathrm{PO}_{4}-\mathrm{P}$ with a mean of $\mathbf{1 . 4 5}$ $\mathrm{mg} \cdot \mathrm{L}^{-1} \mathrm{PO}_{4}-\mathrm{P}$. Phosphorus remediation efficiency varied widely and there was no correlation with water temperature. This 9.31 -acre surface-flow constructed wetland was highly efficient at removing $\mathrm{N}$ from nursery runoff from a 120 -acre catchment (large container production area), although it failed to consistently lower orthophosphate levels in runoff. This type of constructed wetland is suitable for removing oxidized $\mathbf{N}$ forms from nursery runoff and, depending on size, is capable of handling the large volumes of runoff generated by medium to large nursery and greenhouse operations.
\end{abstract}

$\mathrm{N}$ ursery and greenhouse production techniques rely on adequate supplies of water, nutrients, pesticides, and growth regulators to achieve profitable plant

Financial support of this project through the Floriculture and Nursery Research Initiative for Environmental and Resource Management Practices and Strategies, USDA Agriculture Research Service, Ft. Pierce, Fla., is gratefully acknowledged. Mention of a trademark, proprietary product, or vendor does not constitute a guarantee or warranty of the product by the authors and does not imply its approval to the exclusion of other products or vendors that also may be suitable.

${ }^{1}$ To whom correspondence and reprint requests should be addressed. Postdoctoral researcher, Department of Biological Sciences, Clemson Institute of Environmental Toxicology, PO Box 709, Clemson University, Pendleton, SC 29670; e-mail taylor@clemson.edu.

${ }^{2}$ Graduate research assistant, Department of Biological Sciences, Clemson Institute of Environmental Toxicology, P.O. Box 709, Clemson University, Pendleton, SC 29670 .

${ }_{3}^{3}$ Horticultural Resource Manager, Wights Nurseries of Monrovia Growers, Cairo, GA 39828-0390.

${ }^{4}$ Professor, Department of Biological Sciences, Clemson Institute of Environmental Toxicology, P.O. Box 709, Clemson University, Pendleton, SC 29670.

${ }^{5}$ Professor and Chair, Department of Horticulture, Clemson University, Clemson, SC 29634-0319. growth rates. Currently, only pesticides and some growth regulators are under U.S. Environmental Protection Agency (USEPA) directed use and disposal guidelines, although some state and local water quality standards and discharge effluent guidelines apply to nursery discharges (Alexander, 1993). However, federal, state, and local environmental agencies are coming under increased pressure from legislative bodies, special interest groups, and the public to further improve water quality and this will likely include new limits on nutrient discharges. Pollutants originating from horticultural practices include not only pesticides and growth regulators but the $\mathrm{N}$ and P components of fertilizers. Currently, horticultural enterprises are considered non-point sources of pollutants unless an obvious discharge ditch flows from their property into a regulatory agency monitored stream. Therefore, they have fewer regulatory requirements to meet compared to point source polluters (e.g., sewage treatment plants). However, this status will likely change as water quality criteria are tightened either locally or nationally. The exact approach regulatory agencies will take to achieve future improvements in water quality is not known. The total maximum daily load (TMDL) process, which sets a daily maximum quantity of a pollutant that can be discharged into offsite receiving waters, is the anticipated approach. The TMDL process will have a dramatic impact on how nurseries and greenhouses manage irrigation and runoff.

The major impact of nutrients in runoff water from nursery and greenhouse operations is its potential to cause eutrophication of streams, lakes, and estuaries downstream. Although a natural process in water body aging, eutrophication of aquatic ecosystems can be greatly accelerated by increased inputs of nutrients and organic compounds. This can over stimulate phytoplankton growth, which can cloud water and block sunlight and, during algal decomposition, drop dissolved oxygen to levels potentially harmful to fish and aquatic invertebrates. Two of the major nutrients in fertilizers can lead to phytoplankton blooms, $\mathrm{N}$ and P. Excess N (>0.4 mg. $\left.\mathrm{L}^{-1}\right)$ can cause accelerated eutrophication (Vitousek et al., 1997; Wetzel, 1983), harmful phytoplankton blooms (Rabalais et al., 1996), and eelgrass (Zostera marina)

\begin{tabular}{llll}
\hline $\begin{array}{l}\text { Units } \\
\begin{array}{l}\text { To convert U.S. to SI, } \\
\text { multiply by }\end{array}\end{array}$ & U.S. unit & SI unit & $\begin{array}{l}\text { To convert SI to U.S., } \\
\text { multiply by }\end{array}$ \\
\hline 0.4047 & $\mathrm{acre}(\mathrm{s})$ & $\mathrm{ha}$ & $2.471 \mathrm{l}$ \\
29.5735 & $\mathrm{fl} \mathrm{oz}$ & $\mathrm{mL}$ & 0.0338 \\
0.3048 & $\mathrm{ft}$ & $\mathrm{m}$ & 3.2808 \\
0.0700 & $\mathrm{ft}^{3} / \mathrm{acre}$ & $\mathrm{m}^{3} \cdot \mathrm{ha}^{-1}$ & 14.2913 \\
3.7854 & $\mathrm{gal}$ & $\mathrm{L}$ & 0.2642 \\
2.54 & inch(es) & $\mathrm{cm}$ & 0.3937 \\
1 & micron & $\mu \mathrm{m}$ & 1 \\
1.6093 & mile(s) & $\mathrm{km}$ & 0.6214 \\
1 & $\mathrm{ppm}$ & $\mathrm{mg} \cdot \mathrm{L}^{-1}$ & 1 \\
$\left({ }^{\circ} \mathrm{F}-32\right) \div 1.8$ & ${ }^{\circ} \mathrm{F}$ & ${ }^{\circ} \mathrm{C}$ & $\left(1.8 \times{ }^{\circ} \mathrm{C}\right)+32$
\end{tabular}


decline (Burkholder et al., 1992). Phosphorus has also been implicated in eutrophication of freshwater systems and the USEPA recommends total P for surface waters entering lakes and reservoirs should not exceed $0.1 \mathrm{mg} \cdot \mathrm{L}^{-1}$ (USEPA, 1986). However, Daniel et al. (1998) suggested that levels of P between 0.01 and $0.02 \mathrm{mg} \cdot \mathrm{L}^{-1}$ accelerated eutrophication. Nitrate-N in nursery runoff has been reported as between 1.6 and $55.0 \mathrm{mg} \cdot \mathrm{L}^{-1}$ (Alexander, 1993; James, 1995; Yeager et al., 1993) and P between 0.01 and 20 $\mathrm{mg} \cdot \mathrm{L}^{-1}$ (Alexander, 1993; Headley et al., 2001; James, 1995). One means of removing these nutrients from runoff water before it reaches nearby surface or groundwater is through the use of vegetated surface-flow constructed wetlands $(\mathrm{CW})$. Consequently, the objective of this study was to collect data on the efficacy of an established $\mathrm{CW}$ system over 3 years to evaluate its sustained nutrient removal rate over a range of climatic conditions, and identify key factors regulating its performance for nutrient management of nursery runoff water.

\section{Materials and methods}

Site Description. The 9.31-acre wetland remediation system was constructed in 1997 by Wight Nurseries of Monrovia Growers, Cairo, Ga. Data collection for this study began Apr. 2002. The CW system treated runoff water from an approximately 120 -acre catchment with a two-stage surface-flow vegetated wetland design. A wetland stage was defined by the depth of the water within its banks with the first stage having an average depth of 30 inches and the second stage having an average depth of 8 inches. The catchment was used for growing large container trees and shrubs (primarily 50 -L containers) that were microirrigated three to five times daily for 3 to 5 min each cycle as needed. Fertilization was accomplished with a combination of controlled-release fertilizer (CRF) incorporated into the potting substrate and liquid fertilizer injection into irrigation water. Production beds drained into a $1500-\mathrm{ft}$ collection channel that flowed into a 1.0 -acre retention pond. The first $1 / 2$ inch of a rainfall event was captured in the retention pond $(6 \mathrm{ft}$ of pond headspace was required) and excess rainfall was routed over a diversion dam into a storm water retention basin. Water from the retention pond was pumped into two first-stage wetlands that were each divided into three sections by earthen dikes that extended to within 30 to $40 \mathrm{ft}$ of the end of the wetland. At this point water flow from each section rejoined and was allowed to mix before discharge from the first stage. Water inflow was accomplished through three $2^{1 / 2}$-inch i.d. polyvinyl chloride (PVC) pipes (two pipes only for the final section) at a rate of 250 to $350 \mathrm{~L} \cdot \mathrm{min}^{-1}$ per section, depending on daily pump run time. The two first-stage wetlands gravity fed two second-stage wetlands, which were also divided into three sections. Discharge from second-stage wetlands flowed by gravity via a discharge collection channel through two stilling ponds (for suspended sediment finishing) prior to discharge into a nearby stream. Flow through the wetlands averaged $2.1 \times 10^{6} \mathrm{~L} \cdot \mathrm{d}^{-1}$ but exceeded $3.1 \times 10^{6}$ $\mathrm{L} \cdot \mathrm{d}^{-1}$ during periods of excess rainfall (e.g., tropical cyclone systems). Plant cover within the $\mathrm{CW}$ was extensive and multistoried with little open water even during winter months. Plant cover in the first-stage wetlands was dominated by giant bulrush (Schoenoplectus californicus), maidencane grass (Panicum hemitomon), pickerelweed (Pontederia cordata), common cattail (Typha latifolia), floating pennywort (Hydrocotyle ranunculoides), duckweed (Lemna valdiviana), water meal (Wolffia brasiliensis), and alligator weed (Alternanthera philoxeroides). In the second-stage wetlands, dominant plant species included common cattail, pickerelweed, water pennywort (Hydrocotyle umbellata), maidencane grass, floating pennywort, common duckweed, and broadleaf arrowhead (Sagittaria latifolia).

SAMPLE COLLECTION AND ANALYsIs. Beginning in Apr. 2002, water samples were collected monthly at approximately 50 locations throughout the wetland and its receiving stream. Our sampling points in the CW treatment system consisted of: 1 ) six influent samples from the center inflow pipe water fall for each first-stage section; 2) six first-stage effluent samples; 3 ) six second-stage inflow samples from just outside the water fall from the first-stage effluent pipe; 4) six secondstage outflow samples from beside the effluent pipe; 5) six discharge channel samples from 3 to $5 \mathrm{~m}$ downstream of the second-stage effluent pipe and one sample from $30 \mathrm{~m}$ upstream of the first second-stage effluent pipe; 6) single samples of each stilling pond effluent, the discharge channel just before entering an adjacent woodlot, upstream of the mixing point in the receiving stream, and downstream of the mixing point with the receiving stream, including multiple channels when present; 7) seepage within the storm water retention basin that enters the receiving stream; 8) the receiving stream approximately $1 \mathrm{~km}$ downstream and after merging with the creek's main branch; 9) a second retention pond that periodically discharges into the runoff collection channel; and 10) three bed drain channels that merge with the runoff collection channel. All water samples were grab samples representing a particular time and location within the treatment system. Water samples were filtered through $0.2-\mu \mathrm{m}$ polytetrafluoroethylene (PTFE) membrane filters into 1.5-mLion chromatography (IC) vials and stored at $4{ }^{\circ} \mathrm{C}$ until anion analysis with a Dionex AS50 IC with AS50 autosampler (Dionex Corp., Sunnyvale, Calif.). After Sept. 2002, concurrent water samples were taken from key sample sites and analyzed for total nitrogen (TN) and nonpurgable organic carbon (NPOC) using a Shimadzu total organic carbon analyzer TOC-V $\mathrm{CPH}$ with TNM-1 total nitrogen measuring unit (Shimadzu Scientific Instruments, Kyoto, Japan).

Seasonal inflow oxidized nitrogen (defined as $\mathrm{NO}_{2}-\mathrm{N}+\mathrm{NO}_{3}-\mathrm{N}\left(\mathrm{NO}_{-}-\mathrm{N}\right)$ ) or $\mathrm{PO}_{4}-\mathrm{P}$ concentration was calculated as the mean of the monthly means. Monthly means were calculated as the mean $\mathrm{NO}_{\mathrm{x}}-\mathrm{N}$ or $\mathrm{PO}_{4}-\mathrm{P}$ concentration of six samples taken within 1 to $2 \mathrm{~m}$ of the center inflow pipe from each first-stage wetland section. Seasonal discharge $\mathrm{NO}_{x}-\mathrm{N}$ or $\mathrm{PO}_{4}-\mathrm{P}$ concentration was also calculated as the mean of monthly means. These monthly means were calculated as the mean $\mathrm{NO}_{-}-\mathrm{N}$ or $\mathrm{PO}_{4}-\mathrm{P}$ concentration of three samples taken at the end of the discharge channel and from the outflow of each stilling pond. Both wetlands were isolated from groundwater inflow and infiltration by excavation into the Btv horizon, a sandy clay loam with moderate to low permeability. Seasonal water temperatures were calculated as the mean of the monthly water temperatures. Monthly means were calculated as the mean of 24 to 35 water temperature measurements taken concurrently with water 
samples throughout the CW system from inflow through discharge.

Statistical analysis. Data analysis consisted of mean and standard deviation calculations for the months and seasons. Seasons were defined as the months of December through February for winter, March through May for spring, June through August for summer, and September through November for fall. Variables analyzed were $\mathrm{N}$ inflow concentration, $\mathrm{N}$ outflow concentration, $\mathrm{P}$ inflow concentration, $\mathrm{P}$ outflow concentration, and water temperature. All calculations were performed using Excel (Microsoft Corp., Redmond, Wash.) spreadsheet program and data analysis tools.

\section{Results and discussion}

Oxidized nitrogen detected in nursery runoff varied seasonally with nursery production practices but both forms were highly manageable using constructed wetland remediation. The mean seasonal inflow and discharge concentration of $\mathrm{NO}_{x}-\mathrm{N}\left(\mathrm{mg} \cdot \mathrm{L}^{-1}\right)$ and the mean seasonal wetland water temperature $\left({ }^{\circ} \mathrm{C}\right)$ beginning Fall 2002 for the wetland remediation system are shown in Fig. 1. Total $\mathrm{N}$ inputs into the wetland were predominantly from $\mathrm{NO}-\mathrm{N}$ forms. Ammoniacal $\mathrm{N}$ level in the inflow was rarely above 0.25 $\mathrm{mg} \cdot \mathrm{L}^{-1}$. Nitrogen inputs varied substantially and seasonally due to changes in nursery fertilization practices and the quantity of mature plants being sold and replaced with freshly potted plant material on the growing beds but were well within the range reported by Yeager et al. (1993) for eastern U.S. nurseries. Our overall average input of $8 \mathrm{mg} \cdot \mathrm{L}^{-1} \mathrm{NO}_{\mathrm{x}}-\mathrm{N}$ was identical to the mean for production bed runoff of CRF container nurseries as found by Yeager et al. (1993). Highest average input occurred during spring (11.1 to $29.9 \mathrm{mg} \cdot \mathrm{L}^{-1} \mathrm{NO}_{\mathrm{x}}-\mathrm{N}$ ) when fertigation was applied and large numbers of newly potted plants were placed in the growing area. During fall growing periods, mean $\mathrm{NO}_{\mathrm{r}}-\mathrm{N}$ concentrations were slightly higher than summer concentrations and ranged from 6.1 to $9.7 \mathrm{mg} \cdot \mathrm{L}^{-1} \mathrm{NO}_{-}-\mathrm{N}$. This occurred because irrigation water fertilization rates were increased to maximize fall growth flushes by plants.

Minimum $\mathrm{N}$ input occurred during winter $\left(2.8\right.$ to $\left.5.2 \mathrm{mg} \cdot \mathrm{L}^{-1} \mathrm{NO}_{\mathrm{x}}-\mathrm{N}\right)$ when most plants in the nursery were dormant. Although liquid-feeding applications through nursery irrigation water were reduced during summer due to periods of high ambient temperature, which caused some plant species to stop growing, $\mathrm{NO}_{\mathrm{x}}-\mathrm{N}$ levels remained at 6.6 to $7.1 \mathrm{mg} \cdot \mathrm{L}^{-1}$ $\mathrm{N}$ because of the CRF incorporated into plant potting substrate. Mean annual $\mathrm{NO}-\mathrm{N}$ concentration in runoff water was $9.0 \mathrm{mg} \cdot \mathrm{L}^{-1}$, identical to that reported by Huett (1999) for $\mathrm{NO}_{3}-\mathrm{N}$ and slightly below the $10.4 \mathrm{mg} \cdot \mathrm{L}^{-1}$ $\mathrm{NO}_{3}-\mathrm{N}$ reported by Cresswell (1995) from a survey of $13 \mathrm{New}$ South Wales, Australia, production nurseries.

Several researchers have noted a seasonal pattern of $\mathrm{N}$ removal in constructed wetlands and have

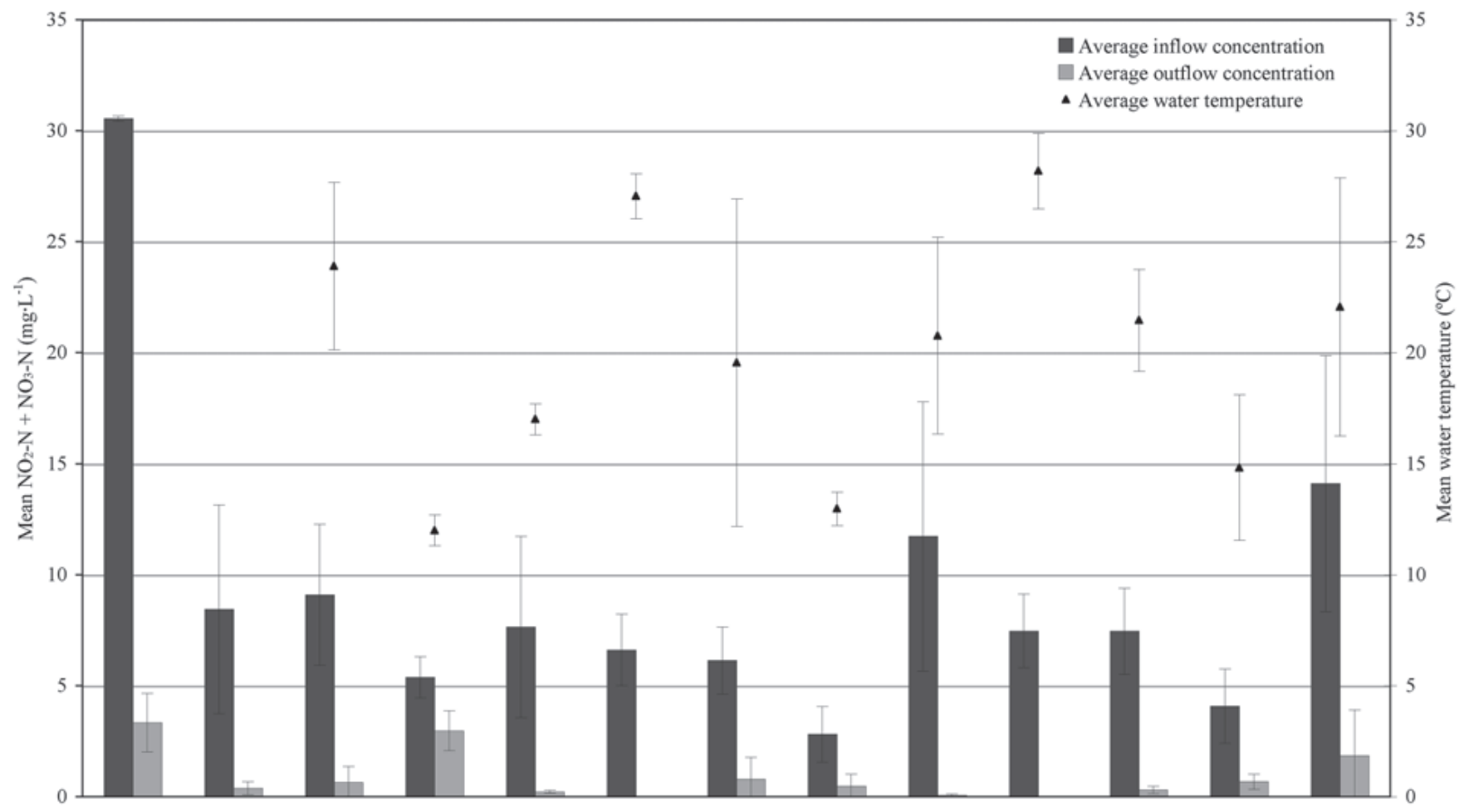

Apr. 2002: June 2002: Sept. 2002: Dec. 2002: Mar. 2003: June 2003: Sept. 2003: Dec. 2003: Mar. 2004: June 2004: Sept. 2004: Dec. 2004: Mar. 2005: May 2002 Aug. 2002 Nov. 2002 Feb. 2003 May 2003 Aug. 2003 Nov. 2003 Feb. 2004 May 2004 Aug. 2004 Nov. 2004 Feb. 2005 May 2005

Sample period (Months grouped into seasons)

Fig. 1. Water temperature (data points) and mean concentration of oxidized nitrogen [nitrate- $\mathrm{N}\left(\mathrm{NO}_{3}-\mathrm{N}\right)+$ nitrite- $\mathrm{N}\left(\mathrm{NO}_{2}-\right.$ $\mathrm{N}$ )] in inflow and outflow water (bars) grouped by months to correspond with seasons (spring, summer, fall, and winter) for a 9.31 -acre $(3.768 \mathrm{ha})$ constructed wetland remediation system located in Cairo, Ga. Water temperature data collection did not begin until Sept. 2002. Error bars represent SD about the mean for the period $\left[1 \mathrm{mg} \cdot \mathrm{L}^{-1}=1 \mathrm{ppm} ;\left(1.8 \times{ }^{\circ} \mathrm{C}\right)+32\right.$ $\left.={ }^{\circ} \mathrm{F}\right]$. 
recognized water temperature as an important cyclic stimulus (Dahab and Surampalli, 2001; Kadlec and Reddy, 2001; Kuschk et al., 2003; Taylor et al., 2003). A similar pattern was found during this study. Nitrogen discharge from the wetland remediation system was greatest and removal efficiency lowest during winter when mean water temperatures were low (10.4 to 15.1 ${ }^{\circ} \mathrm{C}$ ) and average daily temperatures for the month were below $15^{\circ} \mathrm{C}$ (Georgia Automated Environmental Monitoring Network, 2005). Lowest discharge concentrations and highest removal efficiencies occurred during summer when mean water temperatures were above $25{ }^{\circ} \mathrm{C}$. The highest observed discharge concentration $\left(4.28 \mathrm{mg} \cdot \mathrm{L}^{-1}\right.$ $\mathrm{NO}_{\mathrm{x}}-\mathrm{N}$ ) occurred in May 2002 when $\mathrm{N}$ loading was the second highest recorded $\left(31.22 \mathrm{mg} \cdot \mathrm{L}^{-1} \mathrm{NO}_{\mathrm{x}}-\mathrm{N}\right)$; however, remediation efficiency was $86.3 \%$. Compared to prior years, unusually low remediation efficiencies occurred during Mar. and Apr. 2005 (81.2\% and $79.1 \%$, respectively). We attribute this to high hydraulic loading rates (910 and $1073 \mathrm{~m}^{3} \cdot \mathrm{ha}^{-1}$ per day, respectively) following 2-week periods of no loading due to pump problems at the nursery combined with unusually cold and wet weather for the 2 weeks prior to sampling. Over the entire sampling period, remediation efficiency averaged $94.7 \%$ for spring through fall samples, and $70.7 \%$ for winter samples.

Phosphorus is the most recalcitrant pollutant the horticulture industry must address because there is no significant gaseous loss mechanism (Kadlec and Reddy, 2001). This is a consequence of its geochemical cycle. The only long-term unavailable form of phosphorus is deeply buried phosphate bearing rock. Significant portions of organic phosphorus may be tied up as part of peat buildup in CWs (Kadlec and Reddy, 2001). $\mathrm{PO}_{4}$-P concentrations in nursery runoff showed no dramatic changes over seasons and years as shown in Fig. 2. We found that mean seasonal $\mathrm{PO}_{4}-\mathrm{P}$ influent concentration ranged from 0.7 to 2.2 $\mathrm{mg} \cdot \mathrm{L}^{-1}$ with an overall mean of 1.41 $\mathrm{mg} \cdot \mathrm{L}^{-1}$ for all sample periods. This is well below the $5 \mathrm{mg} \cdot \mathrm{L}^{-1} \mathrm{P}$ reported for 13 Australian production nurseries by Cresswell (1995) but similar to the $2 \mathrm{mg} \cdot \mathrm{L}^{-1} \mathrm{PO}_{4}-\mathrm{P}$ reported by Huett (1999) for another Australian nursery. However, it is well above the range of total $\mathrm{P}$ reported by Headley et al. (2001) for four Australian nurseries $\left(0.05\right.$ to $\left.1.5 \mathrm{mg} \cdot \mathrm{L}^{-1}\right)$ sampled in summer and fall.

In this study, mean seasonal $\mathrm{PO}_{4}^{-}$ $\mathrm{P}$ effluent concentration ranged from 0.5 to $2.1 \mathrm{mg} \cdot \mathrm{L}^{-1} \mathrm{P}$ with an overall mean of $1.45 \mathrm{mg} \cdot \mathrm{L}^{-1} \mathrm{PO}_{4}-\mathrm{P}$ for all sample periods, indicating that net $\mathrm{P}$ export likely occurred throughout the wetland system. Mean seasonal $\mathrm{PO}_{4}-\mathrm{P}$ remediation efficiency ranged from an assimilation of $30.4 \%$ (Spring 2002) to

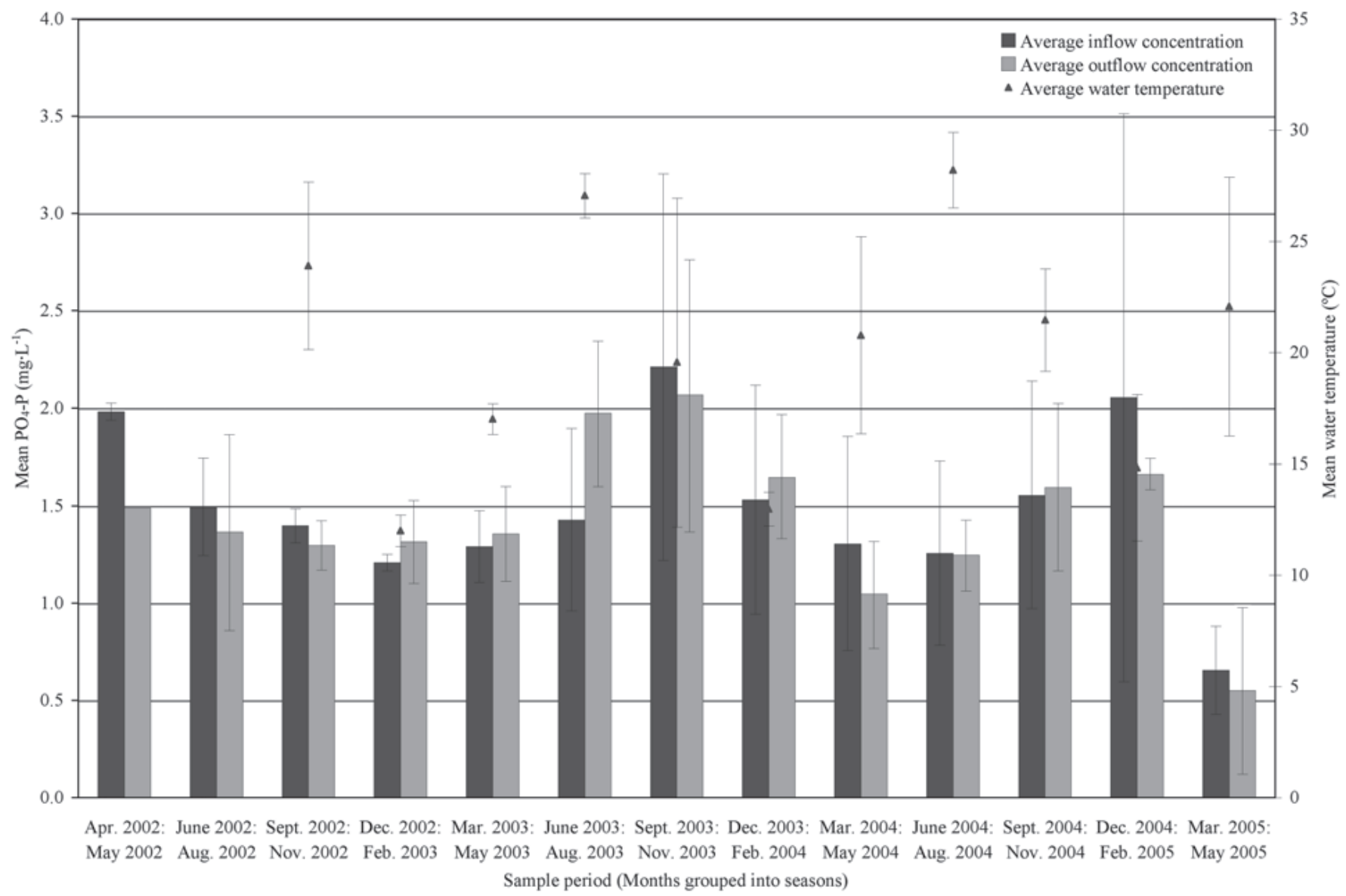

Fig. 2. Water temperature (data points) and mean concentration of orthophosphate phosphorus $\left(\mathrm{PO}_{4}-\mathrm{P}\right)$ in inflow and outflow water (bars) grouped by months to correspond with seasons (spring, summer, fall, and winter) for a 9.31-acre (3.768 ha) constructed wetland remediation system located in Cairo, Ga. Water temperature data collection did not begin until Sept. 2002. Error bars represent standard deviation about the mean for the period $\left[1 \mathrm{mg} \cdot \mathrm{L}^{-1}=1 \mathrm{ppm},\left(1.8 \times{ }^{\circ} \mathrm{C}\right)+32=\right.$ $\left.{ }^{\circ} \mathrm{F}\right]$. 
an export of 39.8\% (Winter 2004-05) but varied widely for months, seasons, and years. Assimilation occurred in three of the four spring seasons and two of three fall periods while export occurred during all summer and winter seasons. Rapid plant growth in the CWs seemed to correspond with periods of $\mathrm{PO}_{4}-\mathrm{P}$ sequestration. This generally corresponded to periods of high orthophosphate levels in runoff, but on a month-by-month basis there was no consistent pattern of removal. Unlike $\mathrm{N}$, there was no correlation of remediation efficiency with the water temperature cycle, although positive remediation occurred during periods of either rapid plant growth (spring) or during late season growth flushes. Kadlec and Reddy (2001) noted an increase in soluble $\mathrm{P}$ at higher water temperatures, suggesting that the mechanisms of $\mathrm{P}$ release are regulated by biological activity. This may account for the consistent export of $\mathrm{P}$ we observed during summer months. Overall $\mathrm{PO}_{4}-\mathrm{P}$ wetland remediation efficiency was $-2.4 \%$ for all sample periods, which spanned the fifth through the eighth years after wetland establishment. Therefore, this monitoring study suggests that over the long term, vegetated surface-flow CWs of this design and loading rate are generally ineffective at removing orthophosphate from runoff and may in fact contribute to stream loading of this nutrient, at least under the conditions encountered at this nursery.

Nurseries have several options for limiting nutrients in nursery discharge water to meet current and future water quality standards. The approach taken depends on several factors, including state water quality standards and discharge effluent guidelines or limits (Alexander, 1993), rainfall pattern and intensity, catchment topography and nursery layout, and the volume of discharge. With proper management of soluble fertilizers, water quality parameters, water-borne disease organisms, and $\mathrm{N}$ and $\mathrm{P}$ levels, recapture and holding ponds can be used to retain potential discharge on-site. The least expensive alternative is to reduce the use of $\mathrm{N}$ and $\mathrm{P}$ to the minimum levels required to achieve profitable plant growth rates and plant quality, as this achieves the goal of cleaner water at both the beginning and the end of production. For horticultural operations that generate large quantities of runoff that require remediation before discharge, surface-flow CWs may offer an attractive alternative. While they do require sufficient land for their construction and are moderately expensive to build and plant initially, surface-flow CWs can be placed on low, unsuitable land and require little maintenance thereafter. This 9.31-acre surfaceflow CW monitored for 38 months was highly efficient at removing $\mathrm{N}$ from nursery runoff from a 120 -acre catchment, although it failed to consistently lower orthophosphate levels in effluent. This type of CW is suitable for removing oxidized $\mathrm{N}$ forms from nursery runoff and, depending on size, is capable of handling the large volumes of runoff generated by medium to large nursery and greenhouse growers. Thus, it is a viable option for meeting regulatory limits on $\mathrm{N}$ in nursery runoff when other alternatives do not achieve the desired goals.

\section{Literature cited}

Alexander, S. 1993. Pollution control and prevention at containerized nursery operations. Water Sci. Technol. 28:509-517.

Burkholder, J., K.M. Mason, and H.B. Glasgow, Jr. 1992. Water-column nitrate enrichment promotes decline of eelgrass Zostera marina: Evidence from seasonal mesocosm experiments. Marine Ecol. Prog. Ser. 81:163-178.

Cresswell, G.C. 1995. Improving nutrient and water management in nurseries. Combined Proc. Intl. Plant Propagators' Soc. 45:112-116.

Dahab, M.F. and R.Y. Surampalli. 2001. Subsurface-flow constructed wetlands treatment in the plains: Five years of experience. Water Sci. Technol. 44:375-380.

Daniel, T.C., A.N. Sharpley, and J.L. Lemunyon. 1998. Agricultural phosphorous and eutrophication: A symposium overview. J. Environ. Quality. 27:251-257.

Georgia Automated Environmental Monitoring Network. 2005. Georgia weatherAutomated environmental monitoring site page. 16 Mar. 2006. <http://www.griffin. peachnet.edu/aemn/cgi-bin/AEMN. pl? site $=$ GACI $>$.
Headley, T.R., D.O. Huett, and L. Davison. 2001. The removal of nutrients from plant nursery irrigation runoff in subsurface horizontal-flow wetlands. Water Sci. Technol. 44:77-84.

Huett, D.O. 1999. Improved irrigation and fertiliser strategies for containerised nursery plants through commercial demonstrations and further research. Final Report NY 95025 to the Horticultural Research and Development Corp., Sydney, Australia.

James, E.A. 1995. Water quality of stored and runoff water in plant nurseries and implications for recycling. Combined Proc. Intl. Plant Propagators' Soc. 45:117-120.

Kadlec, R.H. and K.R. Reddy. 2001. Temperature effects in treatment wetlands. Water Environ. Res. 73:543-557.

Kuschk, P., A. Wiessner, U. Kappelmeyer, E. Weissbrodt, M. Kastner, and U. Stottmeister. 2003. Annual cycle of nitrogen removal by a pilot-scale subsurface horizontal flow in a constructed wetland under moderate climate. Water Res. 37:4236-4242.

Rabalais, N.N., R.E. Turner, D. Justic, Q. Dortch, W.J. Wiseman, and B.K.S. Gupta. 1996. Nutrient changes in the Mississippi River and system responses on the adjacent continental shelf. Estuaries 19:386-407.

Taylor, M.D., S.J. Klaine, and T. Whitwell. 2003. Use of a constructed wetland system to mitigate nutrient contaminants in offsite drainage from a commercial nursery. Proc. Southern Nursery Assn. Res. Conf. 48:468-470.

U.S. Environmental Protection Agency. 1986. Quality criteria for water. USEPA Rpt. 440/5-86-001. U.S. EPA Office of Water Regulat. and Stnd. U.S. Govt. Printing Office (PB87-226759), Washington, D.C.

Vitousek, P.M., J.D. Aber, R.W. Howarth, G.E. Likens, P.A. Matson, D.W. Schindler, W.H. Schlesinger, and D.G. Tilman. 1997. Human alteration of the global nitrogen cycle: Sources and consequences. Ecol. Applications 7:737-750.

Wetzel, R.G. 1983. Limnology. 2nd ed. Harcourt Brace, Fort Worth, Texas.

Yeager, T., R. Wright, D. Fare, C. Gilliam, J. Johnson, T. Bilderback, and R. Zondag. 1993. Six state survey of container nursery nitrate nitrogen runoff. J. Environ. Hort. 11:206-208. 